\title{
EVOLUTION OF THE IMPERIAL RESIDENCE AND URBAN DEVELOPMENT OF THE ST. PETERSBURG CENTER
}

\author{
Leonid Lavrov¹, Fedor Perov² \\ 1,2 Saint Petersburg State University of Architecture and Civil Engineering \\ Vtoraja Krasnoarmejskaja st., 4, St. Petersburg, Russia \\ ${ }^{1}$ leonid.lavrov@gmail.com
}

\begin{abstract}
The scale and nature of the impact of the imperial residence in St. Petersburg on the urban environment of the city center are considered. It is noted that St. Petersburg was a residence city for two centuries, which significantly affected its development. It is emphasized that the Winter Palace was not considered the center of city-planning composition of citywide significance, but gradual development of the residence according to the growing needs of the imperial family had decisive effect on formation of a large area in the historical nucleus of the city.

Periodization for evolution of the area and imperial palace complex is suggested. It takes into account changes in its location in St. Petersburg and its functions, and clearly demonstrates that the culmination of their development was in the first third of the 19th century. It is noted that the area of the imperial residence is currently considered to be the core of the historical city center, but the conditions for adequate grasp of its unique landscape have been constantly deteriorating due to the growing traffic flow in the city. It is recommended to consider the possibility of creating convenient observation platforms on roofs of buildings and in the Neva water area.
\end{abstract}

\begin{abstract}
Keywords
St. Petersburg center, city-planning processes, imperial residences, landscapes.
\end{abstract}

\section{Introduction}

The reviewer of the initial version of this article advised to give more attention to the definition of the "residence city" term. And he had every reason for that. Since the end of the 18th century the interpretation of this notion has presented a challenge. In one of the first guide books on St. Petersburg published in 1790 in German, St. Petersburg was called "a Russian imperial residencecity" ("Rußisch-Kayserlichen Residenzstadt") (Georgi, 1790), and in a new edition published in 1794 in Russian, it was called "a Russian imperial capital city" (Georgi, 2001).

Modern Russian Wikipedia provides only a brief information that "a residence (Late Latin residentia) is a place where the head of the state or government, an ambassador of a foreign state resides") (https://dic. academic.ru/dic.nsf/enc3p/253230).

In German, a residence-city is a settlement where the monarch resides. In such city, the monarch demonstrates to its subjects and representatives of other states his/ her power, which is expressed both in architecture (in particular, in palaces and public buildings) and symbolic events (holidays, processions, parades, royal ceremonies). A residence-city shall represent the power of order and stability in the state (https://de.wikipedia.org/ wiki/Residenzstadt).

The Russian science views residence-cities as a special type of cities. Authors of papers on art history, studying image and aesthetic characteristics of cities as reflection of worldviews, aesthetic preferences and political intentions of the rulers, take an interest in their specifics most often (Kirichenko, 1997a; 1997b; Petrova, 2006).

In this article, we take as a premise that synonyms of the word "rezidentsia" (residence) in the New Explanatory Dictionary of Synonyms of the Russian Language (Levontina, 1995) are "dom" (house), "zhilische" (dwelling), "zhilploschad" (living space)". The impact the imperial residence had on city-planning processes in St. Petersburg is considered at the application level. It is recognized that Russian sovereign rulers had exclusive powers. Russian tsars were considered "the masters of the Russian land" since the 17th century (https://dic.academic.ru/dic.nsf/ dicwingwords/). The tsar could both guide the strategy of the city-planning policy and set specific tasks related to the residence development in person.

During two centuries, a quite developed system of facilities intended to care for the monarch's family formed 
in St. Petersburg and the surrounding area. Table 1 presents those that were official residencies of Russian emperors.

It would be interesting to examine how the development of the central part of the city changed under the influence of the evolution of the imperial residence.

\section{Along the Fontanka River — the Summer Garden area}

The habitable territory of the former manor of a Swedish officer near the expansion of Neva and Fontanka was chosen as a place for a summer imperial residence as early as right after the official foundation of St. Petersburg. In 1712, to celebrate Peter the Great's wedding, a small palace was built on the relatively dense land near Neva, and Catherine the Great's manor house was built to the South, beyond the Moyka River. In 1719, to dry a nearby swampy flat land, the Krasny (Red) Canal and the Lebyazhya (Swan) Canal were dug. In 1725, the Hall for Glorious Ceremonies was built on the Neva bank in the Summer Garden.

The large area became a focus of active transformations that took place after the return of the imperial court from Moscow. In 1732, the luxurious Anna Ivanovna's Summer Palace replaced the demolished Hall for Glorious Ceremonies. At the same time, in the third Summer Garden (where swampy hunting lands of a Swedish officer were previously located), "a jagd garden to chase and shoot deer, wild boars and hare" with a gallery and stone walls "to prevent bullets and shots from flying in" (Ivanova, 1981) was arranged for the august huntress. In the 1740s, the Summer Garden was a ceremonial imperial residence. A special permit was required to enter the garden (http://www.citywalls. ru/house15390.html?s=r0j8f4gfe317fce5jmctqd7qk6). In 1740, implementation of a new large-scale project that would meet Anna Leopoldovna's wishes started. Catherine the Great's "Golden Mansion" was demolished, and a summer palace was built to the South of the Moyka River, while the representative Promenade garden was arranged on the dried land of the future Marsovo Polye (Dubyago, 1963).

When Elizabeth Petrovna became enthroned, everything changed once again: in 1748, Anna Ivanovna's palace on the bank of Neva was demolished, and a regular garden with boskets, summer houses and ponds appeared in the place of the jagd garden. Traces of the Promenade Garden were lost in historical records. The residence palace was finished to meet the taste of the new Empress, and it became known as Elizabeth Petrovna's Summer Palace (http://rusmuseumvrm.ru/ data/collections/painting/17_19/neizvestniy_hudozhnik_ letniy_dvorec_elizaveti_petrovni_tretya_chetvert_xviii_ veka_z_3132/index.php).

Table 1. Imperial residences in St. Petersburg.

\begin{tabular}{|c|c|c|}
\hline Regnal years, the ruler & Winter residence & Summer residence \\
\hline \multirow[b]{2}{*}{ 1703-1725, Peter the Great } & \multicolumn{2}{|c|}{ "Cabin of Peter the Great" on the Petrograd Side } \\
\hline & $\begin{array}{l}\text { Winter House (since 1708) } \\
\text { Wedding Chambers (since 1712) } \\
\text { The first Winter Palace (since 1720) }\end{array}$ & $\begin{array}{l}\text { Summer Palace (since 1712) } \\
\text { Catherine the Great's "Golden Mansion" } \\
\text { (since 1712) }\end{array}$ \\
\hline 1725-1727 Catherine I & The second Winter Palace & Hall for Glorious Ceremonies \\
\hline 1727, Peter II & $\begin{array}{l}\text { Menshikov Palace (1727), } \\
\text { Moscow (1728-1730) }\end{array}$ & \\
\hline $\begin{array}{l}\text { 1730-1740, Anna of Russia (Anna Iva- } \\
\text { novna) }\end{array}$ & $\begin{array}{l}\text { Moscow (1730-1732), the second Winter } \\
\text { Palace (1732-1735), the third Winter } \\
\text { Palace (1735-1740) }\end{array}$ & $\begin{array}{l}\text { Anna Ivanovna's Palace in the first Sum- } \\
\text { mer Garden with the "Jagd Garden" in } \\
\text { the third Summer Garden (1732-1740) }\end{array}$ \\
\hline $\begin{array}{l}\text { 1740-1741, regentess Anna Leopoldov- } \\
\text { na (Emperor Ivan IV) }\end{array}$ & Summer Palace of Peter the Great & Summer Palace of Peter the Great \\
\hline $\begin{array}{l}\text { 1741-1761, Elizabeth Petrovna (Eliza- } \\
\text { beth I) }\end{array}$ & $\begin{array}{l}\text { Third Winter Palace (1741-1755), the } \\
\text { Fourth (temporary) Winter Palace where } \\
\text { Mytny Dvor is located (1755-1761) }\end{array}$ & Summer Palace of Elizabeth Petrovna \\
\hline \multicolumn{3}{|l|}{ 1761-1762, Peter III } \\
\hline 1762-1796, Catherine the Great & The fifth Winter Palace & \\
\hline \multirow[t]{2}{*}{ 1796-1801, Paul I } & Winter Palace (1796-1801) & \\
\hline & Mikhailovsky Castle (1801) & \\
\hline 1801-1825 Alexander I of Russia & Winter Palace & \\
\hline 1825-1855, Nicholas I of Russia & Winter Palace & \\
\hline 1855-1881, Alexander II of Russia & Winter Palace & \\
\hline 1881-1894, Alexander III of Russia & Anichkov Palace & \\
\hline 1894-1917, Nicholas II of Russia & $\begin{array}{l}\text { Anichkov Palace (1894), Winter Palace } \\
(1895-1904)\end{array}$ & \\
\hline
\end{tabular}


When Catherine the Great became enthroned, the interest of reigning monarchs to the Summer Garden area faded. New emperors preferred suburban palace and garden complexes as a place of their residence in summer.

The area on the Fontanka River bank once again became an object of interest for a short period of time in the end of the 18th century. The luxurious Elizabeth Petrovna's residence (by F.B. Rastrelli) was demolished promptly. Even as the heir to the throne, Paul I decided to move the imperial residence from the Winter Palace and was the one to choose the suitable place. The following decree was issued on November 28, 1796 (as early as during the first month of his reign): "to build a new impenetrable castle palace for continuous residence of the tsar. And this palace will replace the dilapidated Summer House" (Bakhareva et al., 2003).

Paul I decided that his personal residence should be similar to Medieval castles that were surrounded by channels filled with water, and that is why he believed that the area of Moyka and Fontanka was the most suitable. $\mathrm{He}$ started preparations for the castle environment as early as in 1797. He accommodated the Kexholm Regiment in a building on the Field of Mars, having evicted the Orphanage from there. It is known that the emperor also did not like a large wooden "Opera House" building nearby, on the Tsaritsyn Meadow... "

$\mathrm{He}$ ordered Mr. Arkharov, a military governor, accompanying him: "Nikolay Petrovich, please, get rid of it!" And he pointed at the theater. According to the legend, in three hours it was as if there had been no "Opera House" at all. In lantern lights, more than five hundred workers were flattening the site where it stood that day" (Sindalovsky, 2012).

By the end of 1800 , a new residence complex was finished, with "das Wasserschloss" ("water castle"), untypical for St. Petersburg, being in the center. Typologically, the castle is related to the Lower Rhine fortifications made during Renaissance. Here, on a large area stretched along the Fontanka River bed, besides the palace, two guardrooms, a drill hall and a stables building were located, and in front of the gate of honor on the Connetable square - Peter the Great's equestrian monument. It is noted that the Mikhailovsky Castle "became a masterpiece of St. Petersburg architecture, but did not blend in with any art movement of its time", and its urban-planning complex can be regarded as an ancestor of outstanding ensembles that would decorate St. Petersburg in the first third of the 19th century (Lisovsky, 2004).

The Mikhailovsky Castle served as a residence for a little more than a month only. After the death of Paul I, the imperial family tried to forget about this building, and there were no new ideas on developing the complex in the Summer Garden area. The unpaved Field of Mars became famous for its clouds of dust raised by marching soldiers, and known as St. Petersburg Sahara. The interest towards this area increased in the beginning of the 20th century when the imperial residence moved to the Alexander Palace in Tsarskoye Selo and autocratic rule was transformed into the Duma monarchy (http:// lawtoday.ru/razdel/biblo/igipr/088.php). In the shortest time possible, a proposal to build a huge State Duma building on the Field of Mars was made, and relevant bidding was arranged (Bass, 2009).

\section{The Winter Palace area - along the Neva River}

Peter the Great chose the area for his first winter residence on the Neva bank in the Admiralty Part, having taken into account various considerations:

- the critical role of the central water area of Neva in shaping the image of a capital city was highlighted. This concept was supported by the Peter and Paul Fortress with a high bell tower of the cathedral, located on the other river bank, and the 400-meter long facade of the Twelve Collegia building facing the Neva expansion;

- the Tsar could view from this place both important construction sites of the new city and navigable passes of Bolshaya Neva and Malaya Neva that were of strategic importance;

- from here it was possible to reach other parts of the city by water, and if travelling by land, the distance both to the Summer Garden and the Admiralty was less than one kilometer.

Peter the Great did not pay any attention to the dignified appearance of his residence: his Winter House is near other structures on the Neva bank and does not particularly stand out. Naturally, when making plans for "the capital city of St. Petersburg", he did not raise any questions related to the location of the imperial palace. Peter the Great's standing also affected further development of the central part of the city: the Admiralty, rather than the imperial residence, became the dominating element of its urban arrangement.

The Winter House on the Neva embankment became larger, was rebuilt and transformed into the Winter Palace by 1723 . After Peter the Great's death, this building was radically upgraded by order of Catherine $I$.

In the 1730s, the city became deserted, and the fires in 1736 and 1737 destroyed more than a half residential houses on Admiralteysky (Admiralty) Island. However, Peter the Great's successors did not make any attempts to move the residence to another part of the city, which attracted court noblemen, high-ranking public officials and their associates and contributed to active development of the southern bank of Neva.

When Anna Ivanovna moved to St. Petersburg, it was decided to enlarge the imperial residence and develop it further to the west of the Zimnyaya (Winter) Canal that had been dug out by that time. Houses owned by Apraksin, the Maritime Academy and Chernyshev were bought out and demolished, and the third Winter Palace was built in their place in 1732-1735. The facade facing Neva was regarded as the front one, and extra technical structures, sheds and stables were built at the back of the building (https://ria.ru/culture/20090627/175487226.html).

By the mid-18th century, this complex "was mottled and dirty and unworthy of the place it occupied, and the very 
oddity of the imperial palace adjacent to the Admiralty on the one side and to the decrepit Raguzinsky's chambers on the other side could not be pleasant for the Empress".

In 1752, Elizabeth Petrovna ordered architect Rastrelli to enlarge the residence and make it more presentable, and for that reason huge size of the designed complex was set (in plan: 210x175 m, height $-23.5 \mathrm{~m}$ ). Neighboring land plots were bought out, and construction works started in 1754. It was Peter III who accepted the completed works in April 1762, and in the summer of 1762 he was dethroned. Catherine the Great became the owner of the palace (Zimin, 2012). She immediately saw its true urban value.

I.E. Grabar (1910) thought it necessary to attract special attention to the activities of Catherine the Great and Alexander I to develop St. Petersburg and called them custodians of Peter the Great's heritage. He did not see "the noble passion for construction (the passion of the Medici, Julius II, Peter the Great and Catherine the Great), this "obsession with architecture", the inexpugnable desire to build, build and build" in many European rulers, but he qualified these Russian rulers as noble sovereigns who made their mark on the world through their city-planning activities and largely defined the image of St. Petersburg.
Catherine the Great established the leading role of the Winter Palace in urban development of this part of the city and paid special attention to its engagement with the Neva water area. The works started when in 1764-1768 wooden slopes that fenced the Neva bank in front of the palace were replaced with a bearing structure. However, the width of the new embankment was considered to be too small, and in 1772-1773, the embankment was rebuilt, with the granite wall significantly outreaching to the water area (Frolov, 2005).

Attention was also paid to the adjacent buildings: the Empress decided to enlarge the residence and erect new buildings to replace the adjacent dilapidated ones. This complex became an experiment in implementation of settings used for development of city blocks: "All houses to be located on the same street should be built as one solid facade with the doorsteps not coming out to the street and the same height along the building line" (Bunin, Savarenskaya, 2017). The facades of the Winter Palace, Hermitage, Old Hermitage became joint, and the Hermitage Theater joined them soon.

At the time, two-story buildings prevailed on the Neva embankments, but for new buildings of the imperial residence, the height of $22 \mathrm{~m}$ was set in 1765 (it was a

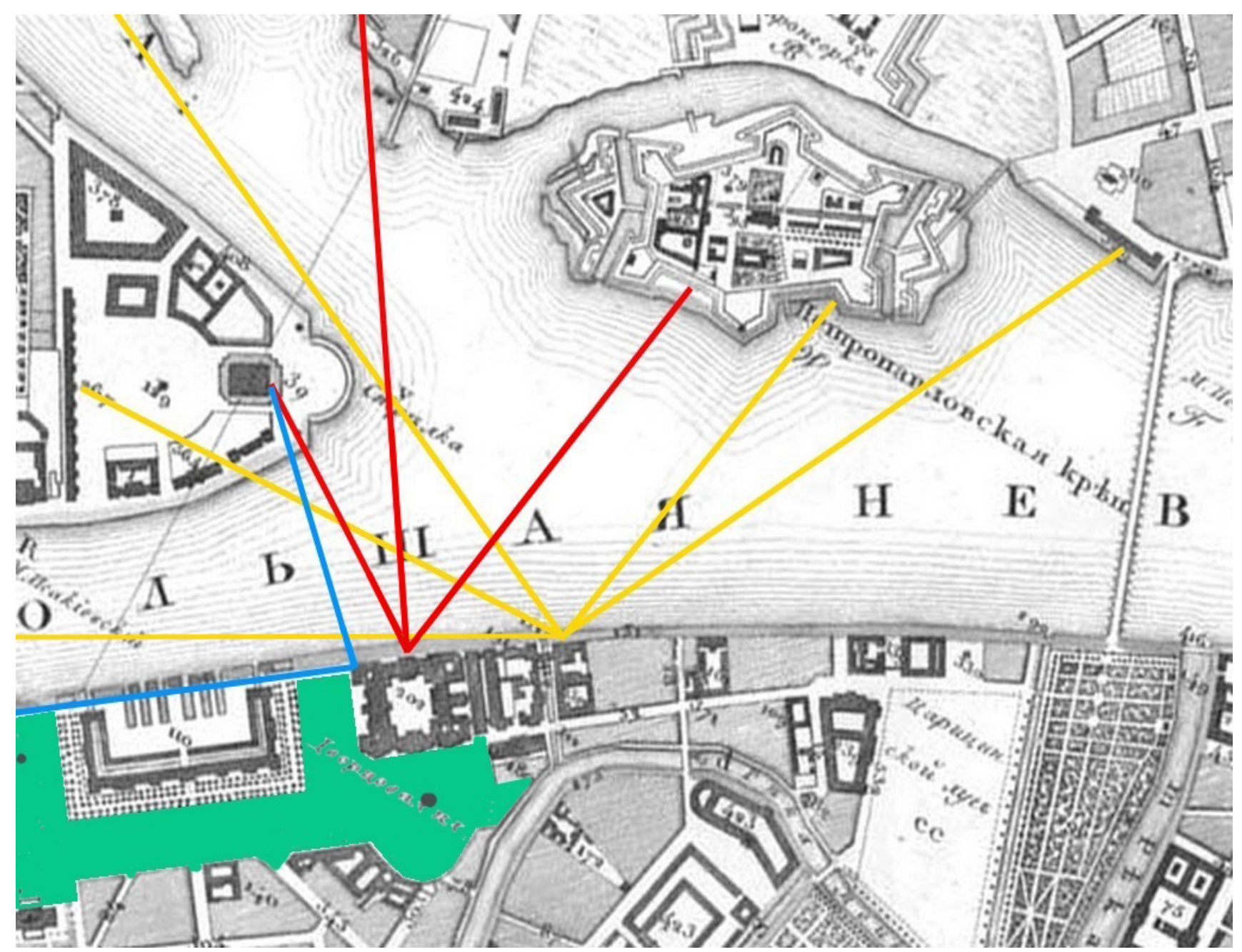

Figure 1. Establishment of the Winter Palace area. Lines of sight are shown in colored lines: yellow — Peter the Great, red - Catherine the Great, blue - Alexander I. The area of the ensemble of central squares is highlighted in green. 
bit lower than the eaves of the Winter Palace), so that "buildings on Neva at least a little bit corresponded to the stone bank created along the river" (Bunin, Savarenskaya, 2017). A single front of representative palace buildings with the height of $22 \mathrm{~m}$ and the length of $400 \mathrm{~m}$ formed on the Palace Embankment. The city-planning direction related to the use of grand buildings, set by Peter the Great at the construction of Twelve Collegia and the Admiralty with $400 \mathrm{~m}$ long facades, Gostiny Dvor with $700 \mathrm{~m}$ long perimeter, and Peter and Paul Cathedral with a $112 \mathrm{~m}$ long spire, was continued. The southern side of the main Neva water area got decent borders.

However, this was not the end. Such parts of the Neva panorama as the gloomy Spit of Vasilyevsky Island and the Petrograd Side that at the time was regarded as outskirts came into the view of the Empress. Their image was not in harmony with the respectable Palace Embankment, and in 1766-1773, by order of Catherine the Great, the Prince Vladimir Cathedral, the unfinished building of which had been seen from the windows of the Winter Palace since 1742 , was reconstructed, and in 1779-1785, brick walls of the Peter and Paul Fortress were faced with stone. In 1783 , according to the design by Giacomo Quarenghi, construction of a stock exchange started, but the empress was not impressed with the building, and the construction was put on hold.

Paul I thought that the Winter Palace was not suitable for residence and planned to arrange for barracks there (as he did with the Tauride Palace) (Zimin, 2012), and that is why he upgraded fortifications of the Admiralty Fortress near the palace. All financial resources were directed to construction and finishing of the Engineers' Castle.

I.E. Grabar pays special attention to Alexander I who became the emperor in the first year of the 19th century, since "Alexander was a direct successor of the Catherine the Great's work, and his passion for construction was not less than that of his grandmother". Alexander I confirmed the role of the Winter Palace as the imperial residence, but he moved his closet to its western part (Zimin, 2012), which played a noticeable role in urban development of St. Petersburg.

Alexander I, like Catherine the Great, paid great attention to the view from the windows of the residence. As early as during the first year of his reign, he noticed an unfinished building of the stock exchange on Vasilyevsky Island and decided to overhaul it. This work was assigned to Jean-François Thomas de Thomon. It was a small facility (central trading floor of the stock exchange had the area of 900 sq. m.), but the project quickly became a cityplanning event of strategic importance.

Applied considerations were relegated to the background, and the main objective was to improve the aesthetic qualities of the landscape of the "central Neva area". I.E. Grabar notes that "...under Alexander's reign, the main task was to build something large, grand, festive", since "he wanted to make St. Petersburg more beautiful than all the European capitals he visited" (Grabar, 1910). It is obvious that since 1804, the complex on the Spit was considered a key facility in implementation of this idea.
Outstanding architects D. Zakharov, G. Quarenghi, I. Lukin and (according to some assumptions) C. Rossi worked on the project. Large volumes of construction works and manufacture of numerous art objects were financed. A soil mass was filled into water to make a semicircular site of more than $150 \mathrm{~m}$ in diameter. Two Rostral Columns, $32 \mathrm{~m}$ high and decorated with sculptures, appeared on the Spit. Under each of them was a stone foundation platform buried $5 \mathrm{~m}$ deep with dimensions in plan of $18 \times 21 \mathrm{~m}$, and a field of piles with the length of $6 \mathrm{~m}$ (Lavrov, Perov, 2016). Granite embankments stretched over $600 \mathrm{~m}$.

The works on the project continued even after the death of Alexander I, when the Collegiate square formed between the Twelve Collegia building and the Stock Exchange, and "one of the most beautiful ensembles of Old St. Petersburg" appeared (Lisovsky, 2004). The expenses for the aesthetics of the Spit paid off: the landscape of the "central Neva area" as viewed from the windows of the Winter Palace was completed and became one of the symbols of the Russian capital.

\section{Winter Palace area - to the Admiralty Meadow}

As for the Admiralty Part area adjacent to the Winter Palace from the west and south, it, unlike the Neva space, did not attract attention of the reigning monarchs for a long time. Under Anna Ivanovna's and Elizabeth Petrovna's reign, the Tsaritsyn Meadow was used to store construction materials, accommodate outbuildings and tend palace cows.

For Catherine the Great, the view from the windows of her closet facing the Admiralty Meadow was not so important: she just ordered to start paving it, and, "by the end of the reign of Catherine the Great, the Admiralty Square became paved, albeit poorly" (Stolpyansky, 1923). Three buildings appearing in 1788 near the Winter Palace formed a small semicircle, which gave the contemporaries grounds to compare the square with an "amphitheater" (Georgi, 2001). It did not attract special attention.

The neighborhood of the imperial residence with the Admiralty shipbuilding manufacture could raise conflicts due to the noise and smell of tar carried by the western winds. However, only after 1782, when a disastrous fire happened in the shipyard, that could easily spill over to the Winter Palace, the scared empress thought that it would be better to move the shipyard to Kronstadt, farther from the palace. The implementation of the idea required time and a lot of money (the Admiralty collegium presented an estimate for 9 million rubles), and that is why it was put into cold storage (http://www.ipetersburg.ru/admiralteystvo).

For Alexander I, the aesthetics of the buildings adjacent to the palace were of interest. In 1805 , a contemporary of the time described "wild and sorrowful disharmony of the Admiralty that due to the height of the earth mound also seemed lower and darker: the view of that discordant scene was unbearable... and it was possible to stare only at one golden spire of the middle tower, inviting to the eye. The considerate emperor surely saw the need for reconstruction of this important building!". The shipbuilding manufacture was moving from the Admiralty to a new 
place, opening good prospects, but financial limitations appeared: "since the times of Empress Catherine the Great, "reasonable economy" has been in greatest request" (Kurbatov, 1913). A lot of money was spent on the Stock Exchange complex, that is why austerity measures were taken for reconstruction of the Admiralty. The author of the concept A.D. Zakharov wrote: "During the development of this draft project, my first rule was to secure benefits for the Treasury. Therefore, I decided not to break old walls and foundations, and that is why only several bare walls were added..." (Sashonko, 1982).

However, when in 1808 the emperor found that the reconstructed and roofed Admiralty building "overlaps with the view from his own chambers on the Galernaya Harbor and the Neva mouth", they had to settle for large costs, demolish the newly built walls adjacent to Neva, and overwork the entire project (Shuysky, 1989) (the demolished area is highlighted in blue in the 1808 layout (Figure 2)). Cost savings were once again a decisive factor when in 1817 the fate of the Admiralty Fortress canals was discussed. A.D. Zakharov wanted to make them look impressive as the Moyka embankments, but it was decided not to spend money and to fill up the canals (Frolov, 2005).

As a result, after the reconstruction, there was a system of squares near the Admiralty, covering this huge complex in a semicircle and naturally merging with the Neva water area. It is obvious that by the end of the first third of the 19th century, the imperial residence area in St. Petersburg reached its climax (Figure 2).

The scale of a huge open space in front of the southern facade of the Winter Palace was impressive: its length was twice the length of the Field of Mars (Figure 2, 1830 layout). A huge ground was an ideal place for ceremonial military parades that distinguished the epoch of Alexander I and Nicholas I who inherited their passion for beautiful military ceremonies from their father. "The St. Petersburg parade was a manifestation of the state and imperial power, and with its visual appeal it decorated the festive space and brought it to the level of the main ceremonial square of the empire" (http://www.peterburg. biz/voennyie-paradyi-i-tseremonii-blesk-traditsiy-i-istorii. html\#ixzz5YHJkNWeU).

During the reign of Nicholas I, the area, free after the demolition of the Admiralty Fortress fortifications, with the length of about $100 \mathrm{~m}$, between the Winter Palace and the Admiralty turned into the Razvodnaya ground used for palace guard mounting. "Almost by the end of the 19th century, a ceremony of guard mounting initiated by Peter III, that was conducted twice a year (in the spring - at the ground between the Admiralty and the Winter Palace, and in the winter - in the Mikhailovsky Manezh) was in the list of military official traditions" (http://www.peterburg. biz/voennyie-paradyi-i-tseremonii-blesk-traditsiy-i-istorii. html\#ixzz5YHJkNWeU). The place was very popular with townsfolk.

People were attracted not only by military formations, but by the spectacular views as directly from the General Staff Building through a wide opening it was possible to see Neva, the Spit with the Rostral Columns and the domes of the Prince Vladimir Cathedral. The feminine part of the imperial family also showed some interest and from a balcony above the Saltykovsky entrance "observed how their husbands, sons and brothers participated in military exercises in front of the palace. In the summer, a green tent hung above the balcony to protect the public against rain and the sun" (Zimin, 2012).

1827 was a landmark as Nicholas I took an entirely new approach to the St. Petersburg architecture. By order of the emperor, on the western facade of the Winter Palace, "chamber" balconies were constructed in front of the closet of the imperial family. The purpose of this decision was exclusively pragmatic: the balconies made it possible to sit in fresh air and take a glance at beautiful urban panoramas. Their possible impact on the imposing appearance and the architectural image of
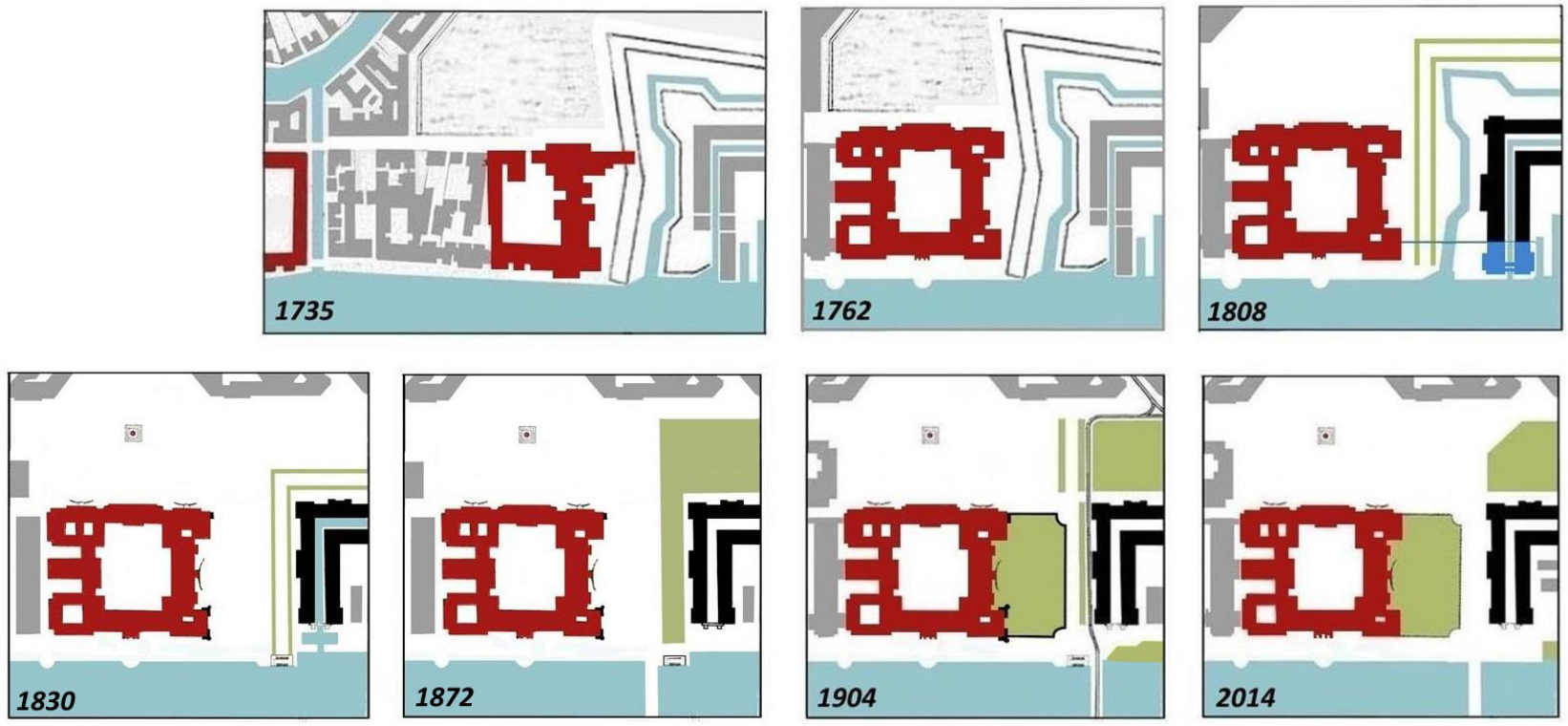

Figure 2. Evolution of buildings in the area between the Admiralty and the Winter Palace. 

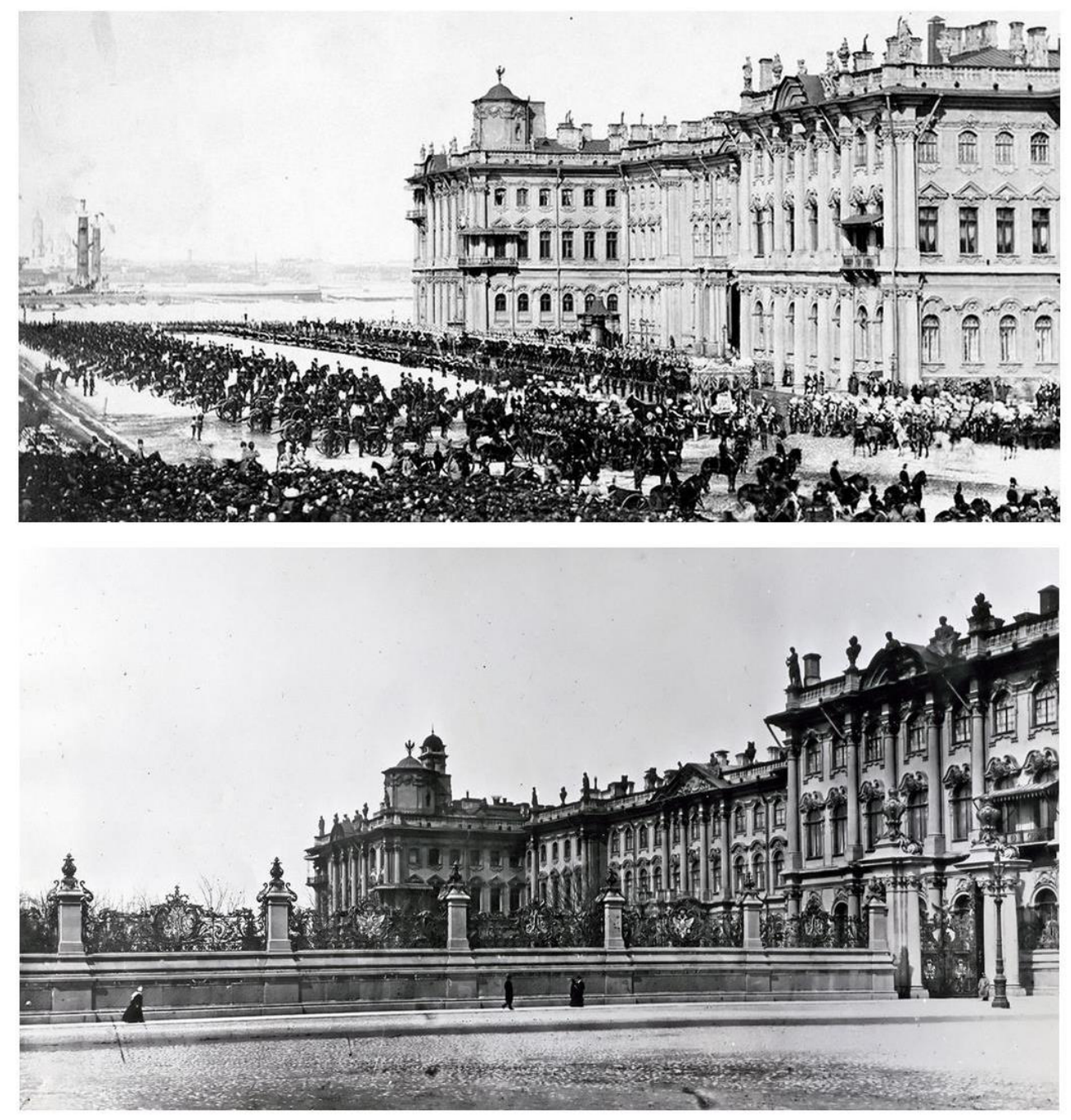

Figure 3. Above: a view of the Razvodnaya ground space in the middle of the 19th century, below: a view of the same space in the beginning of the 20th century.

the building was not considered at all. It is noted that the emperor thought only about the cost of the structure, and he did not take any interest in the architectural aspects ("Both balconies in a "cheap" option were worth 13,600 rubles. At first, Nicholas I was impressed with this figure... However, later, when he got used to the declared amount, the emperor allowed the construction of the balconies") (Zimin, 2012). The balconies that appeared on the facade of the Baroque structure looked weird (especially because they were decorated with textile canopies and shades). But they caught fancy of the residents of the Winter Palace, which is why they were renewed after the fire of 1837. Alien cover pieces disfigured the composition of the Rastrelli's facade for almost a century. The "illegal" structures were dismantled as late as in the 1920s.

One cannot but agree with a critical opinion on his role in the St. Petersburg architecture: "His reign was a turning point in the history of architectural and city-planning activities of the country... It is fair to say that from the first days of his rule, Emperor Nicholas maintained (and in many cases was the initiator of) the initiatives that actually meant rejection of the basic, fundamental principles of the architectural and city-planning policy that had been laid in the first quarter of the 18th century" (Kirichenko, 2010).
However, it is obvious that the limitations made by Nicholas I in 1844 had a very positive impact on development of city landscapes. His order established the limit of height of 11 sazhens $(23.47 \mathrm{~m})$ for all residential buildings built in St. Petersburg: private residential houses could not be higher than the Winter Palace, although it was not directly mentioned in the order.

During the reign of Alexander II, the number of formal guard mounts reduced drastically, and city-planning changes in front of the Winter Palace were initiated. According to P.N. Stolpyansky, normally "the Admiralty square gave a very bad impression". He provided the following description of a contemporary: "Most of the day the Admiralty square is empty... it looks like a cut made inside the capital and filled with historic buildings, but not so vibrant as the center of the outstanding capital should be... Where are people?.. small groups on the steps of the Senate and Synod, some carriages, some pedestrians" (Stolpyansky, 1923). Easy merriment of public festivities, when carousels and ice-hills were built near the palace and noisy townfolk crowded the square, did not appeal to the habitants of the residence. It is not surprising that in 1872, the project of a garden in the place of the squares around the Admiralty, made by the Imperial 
Russian Society of Gardening was "in general approved by the monarch" without any participation of architects. Alexander II "most graciously named the newly arranged garden after himself" (Stolpyansky, 1923). Soon, a dense green mass radically changed the landscape of the central part of the city. High overgrown trees destroyed the unity of the ensemble of the central squares. The space of the Palace Square was limited by the green of the Alexander Garden from the west, but it still had a visual contact with the Neva water area.

They were suppressed at the turn of the 20th century when the majority of the Razvodnaya ground was given to the "own garden of the Winter Palace" that was walled up with a high blind wall (Lavrov, Perov, 2015). As opposed to Nicholas I who located balconies on the facade of the palace without any aesthetic considerations, in this case, Nicholas II personally approved the project and sketches made in the Neo-Baroque style. In 1902, a fence was made along the perimeter of the garden.

It had a stylish effect: an open-work metal wrought lattice crowned a massive wall of slabs made of imported sandstone based on a granite foundation. The new garden with an area of almost 2 ha fenced with the $5 \mathrm{~m}$ high fence made a huge impact on the architectural image of the city center:

- the relationship between the Palace Square and the Neva space was disturbed and the visual connections with Vasilyevsky Island and the Petrograd Side were eliminated.

- the city lost a large public space, there was no more Razvodnaya ground where not only daily guard mountings, but also various public events were conducted.

- presence of sandstone in the structure of the fence surprisingly affected the coloristics of the whole central part of St. Petersburg. By order of Nicholas II, facades of all buildings of the imperial residence, buildings on the Palace Square and many other state-owned structures were repainted in the color of the "new fence of the Own Garden". Color gradations of elements of the order system and plastic decorations, characteristic of St. Petersburg, faded.

Monochromatic terracotta and brick-red colors contradicted the style of Baroque and Classicism buildings, suppressed the variety of their plastic compositions, but made the Russian capital look like European landscapes. "In European cities, sandstone was regarded as a regular decorative stone. It can be seen in Warsaw, Krakow, Poznan, Wroclav, Kielce, Berlin, Potsdam, Hamburg, Bremen, Munich, i.e. everywhere... Reichstag in Berlin. Its entire building is finished with sandstone" (Bulakh, 2009). The damage to the appearance of the city was obvious. The creative community recalled the former "beauty of light multi-shaded colors of St. Petersburg buildings" (Lukomsky, 1910).

They wistfully noted that a part of the Palace Embankment "from the Winter Palace to the Hermitage Theater would be magnificent if the painting of the building was not so depressing... it is disappointing", and the Palace Square "loses a lot because all buildings, aside from the Admiralty, are painted poorly" (Kurbatov, 1913). During the reign of Nicholas II, the Ministry of the Imperial Court, Budget Committee of the State Duma, Military Office, Ministry of Finance and Foreign Affairs repeatedly addressed the tsar regarding building repainting. They thought it was necessary to return the colors approved by Alexander I to the Winter Palace and the General Staff Building. Nicholas II rejected all those proposals (https:// tsars-palaces.livejournal.com/15926.html).

\section{Residence maintenance}

From 1704 till 1918 (with small exceptions), the Cabinet of His/Her Imperial Majesty managed the personal money of the monarchs (so-called "cabinet" money) (http://knowledge.su/k/kabinet-ego-eyo-imperatorskogovelichestva). A lot of matters related to development and functioning of the residences were solved by this office. Initially, the residence in St. Petersburg was quite small, and some of the maintenance functions were localized in direct neighborhood with the imperial family's closets. An orchard, a hennery and fish ponds supplying fresh products to the imperial table were built near the manor of practical Catherine the Great ("Golden Mansion") [43]. However, as early as at the initial stage of the establishment of the residential part of the residence, the Nourishing Palace (a multifunctional base) was constructed. A place near the Summer Palace of Peter the Great, on the opposite bank of Fontanka was allocated for it. Food stores, laundries, and residential houses for the staff were located there (Korentsvit, 2015). The Stable Yard - the center of transportation - developed nearby, on the Fontanka bank.

Many services ensuring the comfort of the imperial family, their relatives and the court were located at the imperial residences or nearby.

Under the project by F.B. Rastrelli, a show ring ("a show ring on the meadow") was built in 1732. In 1732-1735, the third Winter Palace was built. There, aside from residential and ceremonial rooms, there was a gallery, a theater, a large chapel, numerous stairs, service and guard rooms, as well as rooms of the court chancellory. This was not enough, and the palace was rebuilt right after. Technical buildings, sheds and stables were constructed on the meadow side (https://ria.ru/culture/20090627/175487226. html).

\section{Medical facilities for the royal family}

Before Nicholas II, no emperor or empress had ever been to a hospital. They were treated at home, and women of the royal family gave birth also at home. Under the reign of Alexander III, only court medical staff on duty was present in the Winter Palace.

Five physicians in ordinary were hired to the Winter Palace as late as in the end of 1895 when Nicholas II gave back the status of the main imperial residence to the Winter Palace (Zimin, 2012). During the reign of Nicholas II, specialized medical centers for the imperial family members were built "in the walking vicinity" of the Winter Palace: 


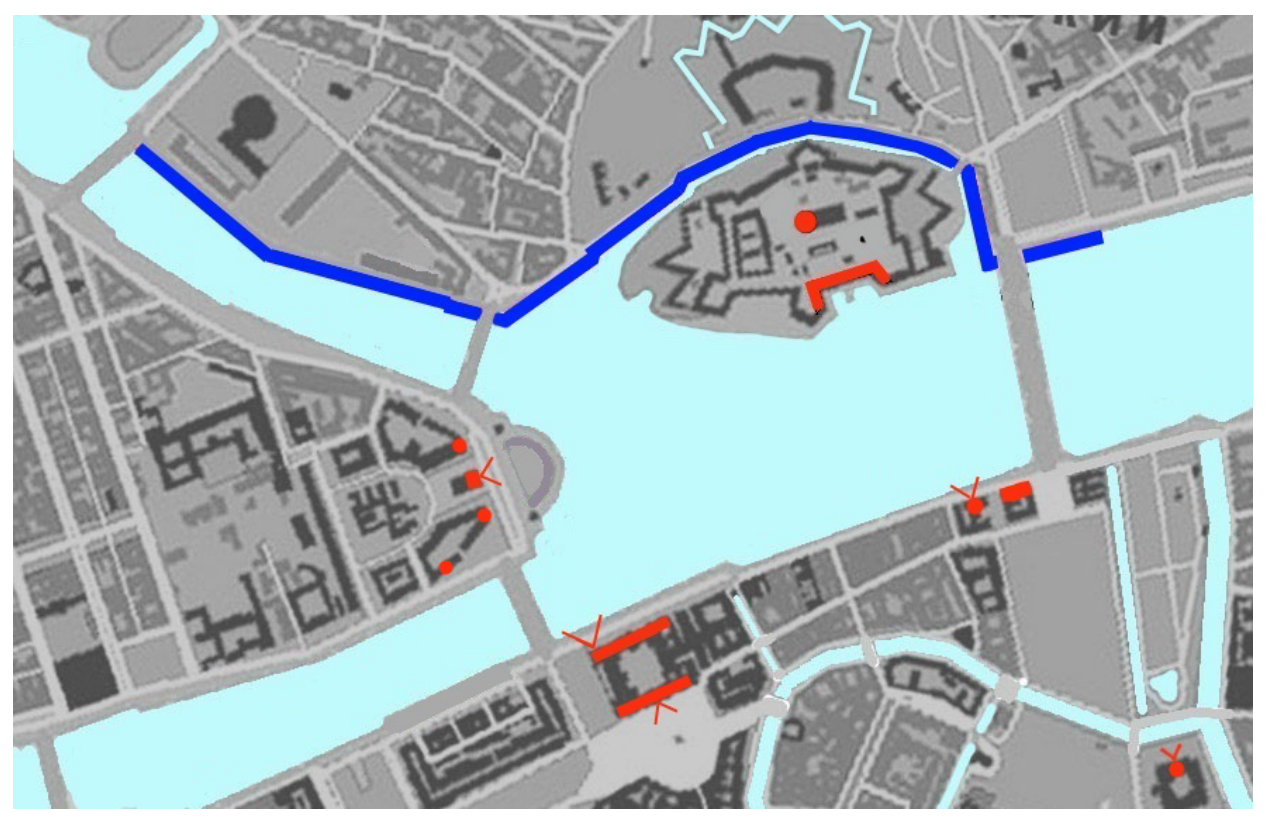

Figure 4. Prospective observation platforms in the area of the imperial residence in the center of St. Petersburg. Platforms on roofs are highlighted in red, and a pedestrian route along the water edge is highlighted in blue.

- in 1899-1904: on the Spit of Vasilyevsky Island, in the center of the Collegiate Square - the Imperial Obstetric and Gynaecological Institute headed by court obstetrician in ordinary D.O. Ott;

- in 1902-1906: on the Petrograd Side, in the Alexander Park - the K.Kh. Horn Orthopedic Institute. Doctor K.Kh. Horn was a physician and massage therapist of the empress, but he did not belong to group of the Court Medical Unit physicians. Nevertheless, the hospital was established as a part of the system for servicing the imperial family: the royal family contributed about 200,000 rubles for the construction, and about 800,000 rubles were given by the treasury. The empress showed her influence, and the land plot for the construction was provided for free, in an area where construction was forbidden (Zimin, Sokolov, 2015; http://www.nvspb.ru/stories/oni-schitalisoshibkoy-56838/?version=print; https://www.zaks.ru/new/ archive/view/72351-10).

\section{Security system}

The 18th century - the beginning of the 19th century was the time of palace revolutions where guards regiments were the active and decisive force, which is why armed guards were the essential part of the imperial residence. In the rear buildings of the Winter Palace, Elizabeth Petrovna accommodated the grenadier regiment that had helped her get the crown. The barracks for the 1st battalion of the Preobrazhensky regiment were built in the end of the 18th century at the corner of the Zimnyaya (Winter) Canal and Millionnaya Street, and later they were rebuilt in 1854-1857.

After the second half of the 19th century, terrorist bombers were the main danger for the royal family. In the first half of the century, Nicholas I "walked from 9 a.m. till 10 a.m. all alone and without any guards. The emperor, wearing a simple greatcoat, greeted acquaintances in a quite democratic way" (Zimin, 2012). After the death of
Alexander II, his son decided not to risk, and Alexander III chose the Anichkov Palace as his residence, where he could walk around the garden fenced from the side of the square by a high blind wall (Lavrov, Perov, 2016). In 1896, based on that model, it was decided to create a safe zone in front of the rooms of the imperial family in the Winter Palace, and make a garden that would be a buffer between the palace and the Admiralty. The implementation of the project started. Special attention was paid to a protective fence, and the project for a safe fence for the garden was viewed and approved by the emperor himself (Zimin, 2012).

\section{Transportation}

It was important for Peter the Great to have daily communications with all parts of the city divided by water, which is why small harbors ensuring mooring of his personal small boat were made for him both in the winter and summer residences.

A slipway in the Winter Palace was intended for winter storage and repair of the boat. To ensure communications of the imperial residence with Moyka, the Zimnyaya (Winter) Canal was dug in 1718-1719. At the same time, the Neva embankment in front of the Winter House was moved several meters to the water area. It also was reinforced with stone, and a berth was constructed there. Probably, those were the first hydraulic works of such kind in St. Petersburg (even construction of a defense facility - the Galernaya Harbor - dates back to a later time). After the death of Peter the Great, his small boat was no longer needed, and the harbor at the Winter House was eliminated during the rule of Catherine I (Malinovsky, 2008).

In the 19th century, attention of the imperial families was attracted to voyages in the Gulf of Finland and farther. Accordingly, the size of imperial yachts increased, and their equipment became better: 
- in 1826-1848, Nicholas I loved to go yachting in his yacht "Druzhba" with the displacement of 163 tons. In 1844, he got a present from England: a two-mast schooner-yacht with the displacement of 257 tons.

- In 1888, for Alexander III, a keel was laid down for the yacht "Polyarnaya Zvezda" at the Baltic Shipyard. It became a part of the Naval Guards. The ship with the displacement of 3750 tons was intended for distant voyages and equipped as a water residence.

The tsar's chambers reminded of luxurious palace rooms and included an entrance hall, a smoking room, a dining hall, two offices (for the emperor and the empress) and two sleeping rooms (for the emperor and the empress). In order to have fresh milk for the children, a room for the cowshed and a cabin for a dairymaid were provided.

- "Shtandart" of Nicholas II was a lot bigger (displacement of 5480 tons), and the imperial residence on board was far richer. Three blocks of cabins (having a living room, a sleeping room and a bathroom each) were provided for the emperor, the empress and the widowed empress.

There was a dining hall, a saloon, cabins for grand princes and princesses, cabins for royal children, cabins for Ladies of the Suite, Maids of the Bedchamber, the Chief Master of the Court, and rooms for servants (http://yachtinform.ru/yahty/imperatorskaya-nikolaya-ii. html). The imperial yachts were docked at the Kronstadt roadstead, and to ensure connection with the Winter Palace, steam boats were used. Respective berths were located along the Palace Embankment.

Nicholas II paid great attention to development of his personal stock of cars. In March 1917, 56 cars were in stock. Their role became greater when the residence was moved to Tsarskoe Selo. Cars were recommended for safety reasons. While in Crimea, the emperor preferred an open car with a canopy, and a limousine-type car was used to travel around the capital (https://tass.ru/spec/ avto_imperatora).

In 1911, a garage for royal cars was built in St. Petersburg (4 years later than in the official residence Tsarskoe Selo). It was located in the yard of the Winter Palace. Nearby, an underground gasoline storage "for 100 poods of gasoline" was built. The danger of a fire was not taken into account in that case (Zimin, 2012).

\section{Conclusion}

- 1703 - the 1750s: during those years, the capital of the empire was a small town representing a conglomerate of various settlements divided by undeveloped lands.

"St. Petersburg left by Peter the Great was a too poor and tiny town for us to consider it as something important" [55]. The poor city-planning situation does not interfere with active development of the residential complex. Places for winter and summer palaces, gardens and even hunting lands were found in the city.

- 1754 - the 1830s: the most fruitful stage of residence development, successful solutions to the task of its imposing appearance; widening the area of the winter residence due to the use of the Neva water area and squares around the Admiralty (the phenomenon of the Mikhailovsky Castle is beyond this strategic direction). The core of the city center formed. An outstanding result was achieved thanks to the targeted use of natural potential due to creative contribution of great architects and corresponding financing of projects ("Moscow was built in centuries, and St. Petersburg - in millions"). The goal of reaching the particular aesthetic parameters played the decisive role.

- the 1870s - 1917: evolution of the complex in the capital was aimed at solving more complicated pragmatic tasks related to safety, recreation and provision of medical services to the imperial family. The residence complex was enlarged due to utility facilities, and the spatial area of the Winter Palace was reduced.

New structures of the residence (the Own Garden, Ott's clinic, and Orthopedic Institute) deform the historical landscapes. A conflict between the residence and the city occurs due to the diverse views on the use of territorial resources of the central part of the city. The imminent change in the political system - the transformation of autocratic Russia into the Duma monarchy showed (https://www.the-village.ru/village/weekend/ read-books/233211-eva-berar).

The official residence of the Russian emperor was moved to the suburbs of St. Petersburg. It turned out that the model of a suburban royal residence created in Versailles in the 17th century met the requirements of the Russian monarch's family in the beginning of the 20th century (http://stadtgeschichtchen.de/artikel/ stadtgeschichte/was-ist-eine-residenzstadt/).

- modern times. The facilities that were included in the imperial residence are currently the basis "of the original structures in Saint Petersburg's historic centre... testament to its outstanding universal value... integrated value as the historic urban landscape".

It is believed that "the city has preserved the authenticity of its chief components", which contributes to the original image of the city and attracts masses of townsfolk and tourists to the center. However, growing automobilization makes it difficult for people to optimistically perceive the unique landscape potential of the city center. Pedestrians are forced away from the embankments by dense traffic flows.

The unique panoramas created during the past centuries cannot be presented in full. We should turn to the lessons from the past to solve the problem: the family of Nicholas II, who could not walk along the Neva embankments freely (although for other reasons), used galleries on the roofs of the residence with great pleasure. Nowadays, terraces overlooking the historical center are arranged on the roofs of museums in Paris and Florence. In St. Petersburg, this experience has been used by the Hermitage and Peter and Paul Fortress where wooden footbridges are installed above the roofs. The expected reconstruction of the Stock

Exchange gives great opportunities: the unique landscapes that can be viewed from the large flat roof rising almost $30 \mathrm{~m}$ above the Neva water area can become 
accessible to people. The view of the historical center from the water level will be ensured by pedestrian routes that can be laid along the embankments on the northern bank of Neva.

Unfortunately, the project "Embankment of Europe" neglected the landscape potential of this place and, therefore, did not provide for a relevant platform neither on the roofs of the erected buildings nor near their footing.
It is obvious that the task of such prospective stage would be restoration of great views on open spaces in the Winter Palace area and provision of the opportunity to view the main facade of the Admiralty. This can be achieved upon reconstruction of green landscapes of the Alexander Garden... The process will take many years, but St. Petersburg is still a young city, and it has a great story ahead of it. 


\section{References}

Bakhareva, N.Yu., Kalnitskaya, E.Ya., Puchkov, V.V. (2003). Mikhailovsky Castle: pages of the monument biography in documents and literature. Moscow: Rossiysky Arkhiv.

Bass, V. (2009). Saint Petersburg Neoclassical architecture of the 1900s-1910s in the context of competitions: the word and the shape. Saint Petersburg: EUSP Press.

Bulakh, A.G. (2009). Stone decorations of Saint Petersburg. Moscow: Tsentrpoligraf.

Bunin, A.V., Savarenskaya, T.F. (2017). History of city-planning art. Streets and embankments. Available at: http://townevolution. ru/books/item/f00/s00/z0000021/st039.shtml (accessed on: 12.01.2019).

Dubyago, T.B. (1963). Russian regular gardens and parks. Leningrad: Gosstroyizdat.

Georgi, J.G. (1790). Russian imperial residence in Saint Petersburg and peculiarities of the area. Saint Petersburg: Verlag C.W. Müller, XVI.

Georgi, J.G. (2001). Description of the Russian imperial capital city of Saint Petersburg and the memorable sites in its suburbs. B.m.: Adamant Media Corporation.

Grabar, I.E. (1910). History of the Russian art. Moscow: J. Knebel Publishing House.

Frolov, A.I. (2005). Saint Petersburg from A to Z. Rivers, canals, islands, bridges, embankments. Saint Petersburg: Glagol. Ivanova, V.P. (1981). Gardens and parks of Leningrad. Moscow: Lenizdat.

Kirichenko, E.I. (1997a). Moscow imperial palaces as a problem of history of art. Moscow: Moscow Architecture Preservation Society (MAPS).

Kirichenko, E.I. (1997b). Concerning two concepts of the imperial residence: Winter Palace in St. Petersburg after the fire of 1837 and Grand Kremlin Palace in Moscow. Moscow: Moscow Architecture Preservation Society (MAPS).

Kirichenko, E.I. (ed.) (2010). Town planning in Russia of the mid 19th - early 20th centuries. Capitals and provinces, volume 3. Moscow: Progress-Traditsiya.

Korentsvit, V. (2015). Summer Garden of Peter the Great. A story about the past and the present. Moscow: Tsentrpoligraf.

Kurbatov, V.Ya. (1913). Petersburg: Artistic and historical sketch and review of the artistic wealth of the capital. Saint Petersburg: Community of St. Eugenia (Partnership of R. Golike and A. Vilborg)

Lavrov, L., Perov, F. (2015). The landscape development of Saint Petersburg (1853-2003). Proceeding of the Institution of Civil Engineers - Urban Design and Planning, 168 (5), pp. 259-266. DOI: 10.1680/udap.15.00016.

Lavrov, L., Perov, F. (2016). Appropriate architecture. Capriccio on the Spit of Vasilyevsky Island. SPbSU Bulletin, 15 (4), pp. 52-86.

Levontina, I.B. (1995). New explanatory dictionary of synonyms of the Russian language. Institute of Russian language. Russian Dictionaries. Moscow: Russian culture languages.

Lisovsky, V.G. (2004). Architecture of Saint Petersburg. Three centuries of history. Saint Petersburg: AO Slaviya.

Lukomsky, G.K. (1910). Architectural chronicle, No. 11. Saint Petersburg: Apollon.

Malinovsky, K.V. (2008). After the Death of Peter the Great. Saint Petersburg in the 18th century. Saint Petersburg: Kriga.

Petrova, O.V. (2006). Gatchina in 1783-1855: a residence town in the context of Russian city-planning culture. PhD in Art History. Moscow: Russian State University for the Humanities.

Sashonko, V.N. (1982). The Admiralty. Leningrad: Lenizdat.

Shuysky, V.K. (1989). Andreyan Zakharov. Leningrad: Lenizdat.

Sindalovsky, N.A. (2012). Legends of Saint Petersburg parks and gardens. Saint Petersburg: Tcentrpoligraf.

Stolpyansky, P.N. (1923). Old Petersburg: Admiralty Island. Labourers Garden. Moscow; Petrograd: GIZ.

Zimin, I.V. (2012). Winter Palace. People and walls. History of the imperial residence, 1762-1917. Moscow: Tsentrpoligraf.

Zimin, I., Sokolov, A. (2015). Charitable activities of the House of Romanov: motivation, traditions and legal forms. Saint Petersburg: Tcentrpoligraf. 